\title{
Communicative Language Teaching in Bangladeshi Rural Schools
}

\author{
Md. Hasan Mahmadun Nuby ${ }^{1}$, Radzuwan Ab Rashid ${ }^{1, *}$, Abu Rashed Md. Mahbuber Rahman², \\ Mohammad Rakibul Hasan ${ }^{1}$ \\ ${ }^{1}$ Faculty of Languages and Communication, Universiti Sultan Zainal Abidin, Malaysia \\ ${ }^{2}$ Faculty of Modern Languages and Communication, Universiti Putra Malaysia, \\ Malaysia \\ Received December 7, 2019; Revised January 10, 2020; Accepted February 3, 2020
}

Copyright $\mathrm{C} 2020$ by authors, all rights reserved. Authors agree that this article remains permanently open access under the terms of the Creative Commons Attribution License 4.0 International License

\begin{abstract}
This study provides a comprehensive investigation into the implementation of CLT in higher secondary level in rural Bangladesh. It reveals that CLT has been espoused minimally by the rural teachers in their English Language Teaching (ELT) classroom. An ethnographic approach was employed to investigate how the rural teachers utilize CLT in their classroom. A total of 46 teaching sessions of two participant teachers from two different schools were observed for six months, from April 2018 to October 2018. Every teaching session lasted for 45 minutes. In total, 34 hours and 50 minutes were spent for classroom observation. Thematic approach was employed to scrutinize the collected data. The research findings revealed lack of exposure to target language, teacher-centred classroom practices, exam-oriented classroom instead of communication-oriented and logistic limitation as the factors affecting the implementation of CLT. Finally, to address these factors for a successful implementation of CLT in rural Bangladesh, this study calls for improved teacher training, examination system with the incorporation of listening and speaking tests, and better classroom facility with technological support.
\end{abstract}

Keywords CLT Curriculum, English Language Teaching, Higher Secondary, Rural Community, Classroom, Bangladesh

\section{Introduction}

The world has become a small cybernetic village with the advent of information and communication technology. Technological revolution has collapsed geographical borders among the countries and promoted the necessity of a common language for communication. Nowadays English appears as the most common language globally for intercultural and international communication. Currently, the number of non-native English speakers has exceeded the monolingual native speakers [1]. English has become the world's lingua franca and accepted as the international language for tourism, commerce and trading, higher education and technology. Therefore, the importance of teaching and learning English is being witnessed in various countries around the world where English is used as second or foreign language; including the south Asian subcontinent which includes Bangladesh.

Since 1992, English has been employed as a compulsory subject from Grade 1 to 12 (higher secondary level) in Bangladeshi national curriculum [2, 3, 4, 5, 6]. However, with the old-fashioned traditional teaching approach (i.e. Grammar Translation Method - GTM), the mission to make students imaginative, creative and competent in English was not successfully achieved. Blind memorisation is prevalent rather than comprehension [7, 8]. Realising the prominence of communicative competence in English, the policy makers introduced the updated English curriculum, CLT-approach, to replace GTM in 1997 [8, 9, 4, 10, 6].

Switching to CLT is seen as a remedial measure in Bangladesh [11], since previously taught grammar-translation method produced students who are very weak in English that they do not have the ability to apply the language in their practical life successfully [9]. The outcome of CLT in Bangladesh is not as successful as it is expected [7, 8, 9, 12]. Although it is recognized and desired by the government that CLT will foster students' communicative competence; most learners in the pastoral areas of Bangladesh leave school with a limited proficiency in English [13, 11]. Students' performance is dismal particularly in the peri-urban regions of Bangladesh. This is because English is no longer the medium of instruction to teach the language; rather English language is taught as a 
subject and instructed with the native language instead of English [9]. Teachers and students do not feel the urge to communicate in English because the main goal of teaching and learning is to pass examination and in the current examination system, there is no provision of testing listening and speaking skills $[13,14,15]$. Therefore, students receive neither the direct touch of grammar as offered by GTM nor the fullest supposed benefits from CLT [16]. Along with proficiency, students' reading and writing skills are also deteriorating as reflected in the high failure rate in English than in other subjects in the nationwide public examinations $[7,11,17,18]$.

This old-fashioned approach of testing format creates shrinkage in the execution of the curriculum and this is a clear indication that the assessment system is inconsistent with the national policy and curriculum $[4,19]$.

The provision of professional training and development programmes for teachers are also inadequate $[10,11,13$, 19]. During the inception of CLT, teachers were the product of GTM and without providing any prior training or considering the local teachers' opinion, CLT was imposed on them [19,20]. Consequently, teaching-learning objectives are not achieved due to the poor performance of the teachers $[10,21]$. Teachers who are not well prepared and trained will not be able to make effective use of the teaching materials no matter how well they are designed [22]. Moreover, a curriculum implemented using top down approach is not efficient [23]. In line with this, Das, Shaheen, Shrestha, Rahman and Khan [24] and Rahman et al. [10] argue that the principles of CLT and teachers' practices are incompatible and teachers do not have clear idea about CLT curriculum rather mixed estimation about its implementation.

Studies have also shown that difficult teaching environment, such as unusually large class size, limited class time, lack of teaching materials, and poor infrastructure contribute to the hindrance of CLT implementation $[5,6,10,25]$. However, many scholars think that teachers are at the core of effective curriculum execution $[23,26]$. In the classroom, it is the teachers who implement the curriculum [27]. Therefore, the present study aims to investigate the practice of CLT by addressing the research question: How do teachers employ CLT approach at higher secondary level in the EFL classroom in rural Bangladesh?

In the words of Ellis [28] "language learning requires the detailed investigation of usage, its content, its participants, and its contexts" (p.39). Therefore, it is crucial to explore current practices to ensure the best practices of CLT. Despite the comprehensive research in CLT application, limited research has been done in the rural environments of Bangladesh. Since rural teachers' activities may vary from urban teachers' activities, it is worth considering their roles in CLT implementation. This study is important as it could be used as a resource that gives a vivid picture of CLT implementation of Bangladeshi rural EFL context.

\subsection{CLT in Different ESL/ EFL Community}

The shift from grammar-focused instruction to CLT in curriculum implementation has been the subject of study across various ESL/ EFL settings [e.g., $29,30,31,32,33,34,35,36,37,38]$.

The study of Athawadi [31] shows that the absence of teaching resources, teacher training, non-qualified learners and education system hinders CLT implementation in Libyan university English classes. The study calls for adequate in-service training for teachers to improve the implementation of CLT. In Ecuador, Toro et al. [38] indicate that pair work, group work, modelling and repetition are not enough to promote active classroom participation as these learning strategies are not properly executed. The study suggests the employment of strategies like metalinguistic feedback and elicitation, which can benefit students to develop their oral skills. Luo and Garner [33] in China assert that due to the deeply Confucian culture, learners are preoccupied with passive learning from the teacher instead of engaging in active participation. Similarly, Smith [36] reveals that Japanese learners are typically reserved and they are unwilling to interact in English because they feel they are bad English speakers. In Japan, grammar-focused examinations, influence of traditional teaching methods and the university entrance exams pressure are the reasons which affect CLT implementation [35,37]. The study of Mason and Payant [34] discloses that teachers' belief and practice are not aligned as well as contextual issues hinder CLT implementation in Educator. In Indonesia, Susanto [39] shows that the application of CLT is effective when it is incorporated with extracurricular activities. In the same vein, Astuti [29] and Astuti and Lammers [30] suggest the use of Cooperative Learning (CL) to improve communicative competence. Whereas, Muthmainnah [40] proposes the idea of English Corner, an arranged space to practice English for improving students' English skill in Indonesia.

\subsection{Communicative Language Teaching (CLT)}

The root of CLT is found in Hymes' 'communicative competence' theory [1,41] in which he states that communicative competence is the ability to use language appropriately in different circumstances [42]. Centred on Hymes' communicative competence theory, in the late seventies, Widdowson [43] developed the concept of communicative language teaching [1]. Before this time, fundamental structures, Audio-Lingual Method (ALM) and Grammar Translation Method (GTM) were practised when language teaching was utilised for teaching English as a foreign language in British Situational Language Teaching approach. CLT appeared as a result of the dissatisfaction of structural teaching method $[25,44,45]$.

CLT was embraced and implemented rapidly, as it gained reputation quickly in British language teaching 
circles which involve leading British applied linguists, textbook writers, specialists of language teaching, curriculum development centres, publishers, in addition to institutions, such as the British Council. Both American and British proponents recognized CLT as an approach that emphasizes mainly on communicative competence and learning integrated language skills for meaningful communication [46].

Over the years, many applied linguists have theorized CLT. However, Richards and Rogers [46] propose that the most commonly recognized theories of CLT are:

- Emphasis should be placed on the assimilation of meaning, linguistic form and function.

- Learners should be involved in pragmatic, functional and authentic use of language for meaningful purposes.

- Complementary principles underlying communicative methods are fluency and accuracy.

- Classroom teaching should focus on working in pairs or groups.

- Fluency and accuracy assessment should be conducted.

- The native language of the student should be avoided.

- The role of the teacher is to facilitate learning for the students.

The key features of CLT have always been to emphasize meaning over linguistic accuracy. CLT focuses on meaningful oral and written operations to support learners' communication skills [47]. According to the teaching and learning philosophy, it is contrary to the rigid grammar guidelines of GTM or repetitive drilling of the ALM. In a CLT classroom, the centre of power changes from teachers to learners by enabling them to communicate with each other and providing learners with ample opportunities to work in pairs or groups. In doing so, teachers take on the function of facilitator rather than the centre-force of a language classroom [46].

\section{Methodology}

This study aims at exploring how English language teachers implement CLT at higher secondary classroom in rural Bangladesh. The researchers employed a qualitative research approach whereby data was collected from classroom observation to scrutinise the day-to-day operation of CLT at the two colleges located in the peri-urban region of Bangladesh. Applying interpretive theoretical viewpoint, this qualitative enquiry helped to gain an in-depth understanding of the phenomenon being investigated. Creswell [48] denotes "a qualitative study is defined as an inquiry process of understanding a social or human problem, based on building a complex, holistic picture, formed with words, reporting detailed views of informants, and conducted in a natural setting (p.34)". The paucity of existing research is that most of them used interview and questionnaire data to collect data [49]. However, very few studies have tried to observe the classroom as a tool to investigate what teachers do in their classroom [50]. Classroom observation is regarded as the heart of the qualitative research design in curriculum implementation studies as it delivers first-hand information on the execution of any programme [51].

Ethnographic approach allows researchers to "capture the character of naturally occurring human behaviour" by "first hand contact with it, not by inferences from what people do in artificial settings like experiments" [52, p. 6]. This prospect enables the researchers to provide a "thick description" [53 p. 316] of the phenomenon where information was gathered from "up-close, personal experience and possible participation, not just observation" $[54$, p. 1] of the participants' real life environment for a considerable period of time [55].

This study began data collection procedure with ELT classroom observations of the two participant teachers of two colleges for six months (from April to October, 2018). The classroom observations were limited to two teachers of two different colleges so that more time could be spent with them to gather rich insights into their practices of CLT. The colleges were selected based on the access availability.

The English language classes were held four days out of the six working days in a week as only one English language teacher was there in both colleges. As a non-participant observer, the first author observed 46 teaching sessions of the two participant teachers to examine the activities and tasks carried out. Creswell [48] states that a non-participant observer is an outsider of the group under study who can watch and take field notes from a distance without direct involvement. Regarding this, Hennink, Hutter and Bailey [56] suggest "non-participant observation is not observing through deception but is observing with a purpose and from a distance" (p. 185). In addition, classroom observation is a research method that enables researchers to systematically observe and record people's behaviour, actions and interactions. The method also allows researchers to obtain a detailed description of social settings or events in order to situate people's behaviour within their socio-cultural context [56, p.170].

In other words, classroom observations will help the researcher to involve with the real classroom settings where teachers' actual role will be demonstrated rather than what they think to do. In line with this, Cohen, Manion and Morrison [57] argue that observation "enables researchers to see things that might otherwise be unconsciously missed, to discover things that participants might not freely talk about in interview situations" (p. 396).

The observation over a period of six-months was planned with the aim of ensuring in-depth experience and understanding to grab the participants' genuine activities, experience and emotion. At the same time, prolonged observation reduces the researcher effect that the observer could have on the context. It was intended to make the 
teacher and students feel at ease so that they behave more naturally in the presence of the researcher in the classroom. Moreover, the researcher did not set any video camera and tried not to make eye contact with the teachers and students during class hour which could affect teachers' and students' normal practices.

After observing the lesson, the researcher took photographs of the classroom, textbook, teachers' work, students' work, and any posters, which were later used to interpret the data. The collected data was written in the form of field notes which included the "descriptions of contexts, actions, and conversations" [58, p.77].

\subsection{Data Analysis}

To analyse the observation data, thematic approach was applied. The analysis is made up of topic selection, category selection and theme selection as recommended by Luttrell [61]. After transcribing data along with the field notes, the researchers scrutinize the scripts to develop a general understanding of the participants' practice of CLT in their contexts. The researchers acquainted themselves with the field notes and data by continuously scanning the transcribed data in an active way to search for patterns and meanings [62]. This phase is named "topic selection" by the researchers, as "topics" are identified in this phase from the data. 'Using mother tongue' is one such topic. During the second review, the researchers determine the relations among the similar topics and put them in one category as "category selection". A "category" is meant in this research as a group of topics with common features that form a similar larger concept [63]. Examples for such topics are "Teacher's proficiency in English" and "Skipping communicative activities" that refers to the common matters observed in teachers in CLT implementation. Both refer to insufficient usage of target language and are therefore grouped under the category "Using mother tongue instead of target language". Once categories are labelled, the study starts to scrutinise them again to define theme that emerge across the data as "theme selection". From this exercise themes are developed. Theme is defined in this study as a set of categories presenting a concept or quality that is unifying and recurrent.

\section{Findings and Discussion}

The findings reveal that CLT at higher secondary level in rural Bangladesh is implemented in a marginal way. The themes (i.e lack exposure of target language, teacher centred classroom, focusing on exam instead of communication and logistic limitation) reveal the restrictions of CLT implementation.

\subsection{Lack Exposure of Target Language}

Using target language in the classroom is one of the major principles of CLT. However, Bangla was dominantly used as the medium of instruction in the two observed schools. In CLT classroom, judicious use of mother tongue is permitted but to explain tasks from textbook or communicative activities, target language should be used [64]. Throughout the observation period, the teachers were commonly found to read out the passages of different lessons loudly for the learners and translated them into native language line by line. They wrote new words on the board and explained word meaning in native language in their reading activities. Students hardly spoke English. They used English only when they answered questions of any lesson which is basically based on their memorization. The objective of CLT approach is to improve students' speaking skill in the target language. Hence, it was expected that teachers would inspire students to speak in English in classroom and develop their speaking skill. In reality, the teachers were found to use native language in all types of classroom activities and communication, let alone encouraging students. The study of Rahman et al. [10], Roy [6], Trisha et al. [7] also found similar problems in CLT implementation.

\subsubsection{Teacher's Proficiency of English}

During the inception of observation days, both teachers tried to speak in English though it was very limited. Gradually, when they became accustomed to take their class in the presence of the observer, they started behaving casually. The teachers' ability in speaking in English was unsatisfactory. They kept their English speaking confined to some limited words like 'yes', 'no', 'very good'. It is disheartening that the observed teachers in the rural areas of Bangladesh were unable to speak in English fluently. They used mother tongue instead of English in teaching English in the classroom. In regular classes, the teachers spent maximum class time in delivering lecture in Bangla instead of using the target language. English was only heard when teachers read the text. Teachers' limited proficiency is a barrier in CLT implementation in the rural colleges. This problem is also acknowledged in other studies conducted in the rural areas of Bangladesh regardless of education level [e.g. 10, 65, 66].

\subsubsection{Skipping Communicative Activities}

Almost in every class observation session, it was noticed that only some segments of the textbook were read out and the communicative part of the text, such as group work, pair work and other communicative activities were left out. The teachers only conducted reading activities though the textbook offered speaking activities as well. Whereas, communicative activities like group and pair work, role play, and dialogue are the integral parts of CLT classroom and without practising these activities, students will not be able to develop their communicative ability [46]. As speaking and listening skills remain untested in the examination in Bangladeshi curriculum, this could be the 
reason of skipping communicative activities. Some other researchers also pointed out of avoiding communicative activities in the classroom and the problem related to limited use of target language in the classroom, which led to the failure of CLT [e.g. 7, 13, 14, 17, 65, 84].

\subsection{Teacher Centered Classroom}

The two teachers employed very similar teaching techniques. They presented their lessons in lecture form and spent most of the time delivering lectures to the students. Student participation in any conversation was very limited. They were only involved to answer or solve any close or open ended question and any grammatical terms. They did not take part in any interactive activities such as group work, pair work, role play etc. Active interactions were completely absent. The students remained passive and shy in front of their teacher and classmates. They listened to lectures passively and remained mute. One way communication was commonly observed where the teachers were the speakers and students were merely the listener.

The two teachers did not maintain the CLT-oriented teaching practice. Their teaching approach can be described as "authority-oriented" [79] where learners "prefer the teachers to explain everything, liked to have their own textbook, to write everything in a notebook, to study grammar" [80]. Such type of traditional teaching approach neglects some other types of students, who were "concrete" students, "analytical" students and "communicative" students [80 p. 170]. The teachers were not maintaining the role of "facilitator and guide" as endorsed by CLT principles; rather they were assuming "an all-knowing font of knowledge" [81 p. 47]. It was observed that the students were unoccupied and unattended in most of the classes as their role was not participatory in the class and the teachers were always busy in presenting either grammar structure deductively or reading passages monotonously.

\subsubsection{Formal Classroom Interactions}

It seemed that the students were very formal in interacting with their teachers in the classroom. This could be the Bangladeshi rural cultural effect where students are found passive, obedient, and shy $[78,6]$. The prevalent notion is that teachers must be honoured and considered as the central figure and students must obey and listen to their teachers passively [79]. The students were not encouraged to ask any questions to the teachers. Their relationship had been developed in such a way that students could hardly dare to ask any question, interrupt their teachers, let alone argument. This type of cultural practice genuinely prevents communication to take place among teachers and students in class; above all, hinders the application of CLT [6, 73, $79,82]$. With the teacher being adorned the 'guru' role, normally the classroom environment become teacher-led.

\subsection{Exam Oriented Teaching Instead of Communication}

Classroom activities are very much exam oriented. The teachers often pointed out which lessons are important for the examination. Since there is a clear mismatch between the curriculum and examination system, the CLT classrooms deviated from its norms and principles. Although the curriculum targets to improve the learners' integrated skills of speaking, listening, reading, and writing in the target language, the assessment pattern swayed the teachers to emphasize on reading and writing skills and ignore the other two skills [66]. The problem of a limited operational curriculum does not ensue only in Bangladesh. Similar tendencies have been acknowledged and reported by the researchers in other countries for example, in South Korea [68], Israel [69], Japan [70, 71], and China [72].

\subsubsection{Use of Model Test and Guide Book}

For teaching and learning purposes, students and teachers are forbidden to use guidebooks by Bangladeshi government [65] though these exam preparatory books are available in the market [17]. However, the two teachers used the guide book very frequently. The meaning of the passage, vocabulary and questions-answers were usually referred to the guidebook. Bangla translation of the passages o is given in the guidebook as well as other items like word meaning, answer of close/open ended question, paragraph, and letter. Alongside the guide book, the teachers and students were noticed to follow model test book, which contains the past exam papers of all the education boards and a plethora of mock test. Using model test and guidebook could make the exam easier for the students but their creativity gets nipped in the bud.

Given the objectives of CLT, the teachers should involve students in communicative activities so that they can drill and develop their communicative skill in the classroom. Using guide book and model test book only encourages the students to memorise their lessons.

\subsubsection{Influence of Grammar Translation Method}

The two teachers are still influenced by the traditional teaching method, Grammar Translation Method, which contradicts CLT pedagogy. This contradiction causes difficulties in CLT implementation. Throughout the observation sessions it was noticed that the teachers mainly carried out extensive reading activities or presented grammar forms. Reading activities were confined to translating the text and difficult word meanings in native language. Grammar teaching was involved with presenting tense, voice, narration, and transformation of sentences by means of out-of-context memorisation. Students were not seen to involve in any authentic environment for the practice of communication. The teaching-learning process in the classroom was a matter of transmitting knowledge. Many other scholars also identify that influence of previous traditional methods which inhibit CLT implementation [e.g 
$65,66,73,85]$.

\subsection{Logistic Limitation}

Logistic limitation is another problem which affects the implementation of CLT. For instance, it involves large class size, lack of teaching aids and poor infrastructure. In the classrooms observed, the average number of students is 70 to 80 . It is certainly difficult to ensure quality teaching in such a huge classroom while class time is only 45 minutes.

Undoubtedly, large classes decrease the possibility of students' interaction with their teachers and classmates. This could be the cause of avoiding communicative activities in the large classroom. Classroom management could be a difficult task for teachers if the class is too large. According to CLT standards, the number of students should not be more than 15 or a few in a class [22, 74]. Lack of teaching and learning material is another problem related to classroom conditions. The observed classrooms had no audio visual equipment. The teachers were also never seen dealing with any other teaching aids like posters, magazines, pictures, maps or cue cards.

The only teaching materials found in those classrooms were blackboard, chalk, duster, textbook and guidebooks. McGrath [75] claims that teaching aids play an important part in teaching and learning any foreign language. In line with this, Brown [76] asserts that teaching resources help the classroom participatory. However, due to the lack of teaching materials in the classroom, CLT implementation was affected in the rural colleges. Insufficient teaching materials and technology has also been explored in other studies as the cause of incomplete CLT implementation [13, $17,65,66,73,83]$.

Several other challenges were identified throughout the classroom observations, such as shortage of teachers, limited class hour (e.g. 45 minutes per class and 3 to 4 days in a week), cancellation of classes, pressure of finishing syllabus, ill setup of furniture in the classrooms and building infrastructure, lack of language labs, and the teachers' attitude which is not useful to build rapport with the students. However, it must be noted that the findings do not necessarily show that the teachers were poor performers. Rather, it highlights that their teaching practices are not aligned with the principles of CLT which are "highly contextualized" [77 p. 217].

\section{Recommendations and Conclusions}

Introducing CLT at higher secondary level curriculum in Bangladesh provides opportunities for learners and teachers to improve their English skill. However, the practice of CLT in the rural EFL community does not replicate the methodological facets recommended by Richards and Rogers [46]; Larsen-Freeman and Anderson [47]. In fact, in the rural context of Bangladesh, the implementation of these methodological facets of CLT is being hindered by many issues. To overcome those issues some suggestions are given below:

1. Teachers should be provided with enough training even the piece-meal ones, and not only on pedagogical aspect of CLT but also for developing their own English proficiency.

2. Examination system should be formatted by incorporating the listening and speaking tests. Until the listening and speaking tests get incorporated in the examination system, teachers and students will never feel the urge of practising communicative activities.

3. Teachers and students should be motivated and encouraged to take part in communicative activities through group and pair works, information transfer, and role play.

4. For proper CLT implementation, classroom should be equipped with the technological devices like projector, computer, sound-system and necessary teaching materials.

5. The main principle of CLT is interaction. To materialize interaction, teachers should come forward to remove students' English phobia by developing a good rapport with them.

Above all, teachers and students need to realize that English learning is not only for examination purpose. It is an international language to be used meaningfully for communication in many aspects of life.

\section{REFERENCES}

[1] M. K. Ibrahim, Y. A. Ibrahim. Communicative English language teaching in Egypt: Classroom practice and challenges. Issues in Educational Research, Vol.27, No.2, 285-313, 2017.

[2] R. Chowdhury, A. H. Kabir. Language wars: English education policy and practice in Bangladesh. Multilingual Education, Vol.4, No.1, 4-21, 2014.

[3] J. S. Karim. The Role of Classroom Environment in Learning English in Bangladesh: HSC Level (Unpublished Master's thesis). East West University, Bangladesh, 2018.

[4] S. Nur, M. A. Islam. The (Dis) Connection between Secondary English Education Assessment Policy and Practice: Insights from Bangladesh. International Journal of English Language Education, Vol.6, No.1, 100-132, 2018.

[5] M. M. Rahman, A. Pandian. A Critical Investigation of English Language Teaching in Bangladesh: Unfulfilled expectations after two decades of Communicative Language Teaching. English Today, Vol.34, No.3, 43-49, 2018.

[6] S. Roy. Challenges to Implementing Communicative Language Teaching (CLT) in Bangladesh. Language in India, Vol.16, No.3, 218-235, 2016. 
[7] B. J. Trisha, M. S. Akter, I. N. Yusufi, A. S. Munna, Dissonance between Syllabus and Testing: Reason of Weak Efficiency in English at SSC Level. Current Educational Research, Vol.1, No.1, 1-5, 2018.

[8] A. Karim, A. R. Mohamed, M. M. Rahman, M. H. Haque. Teachers' dilemma bog down CLT in EFL contexts: A discussion on EFL teachers' beliefs and sources. IOSR Journal of Humanities and Social Science (IOSR-JHSS), Vol.22, No.4, 112-120, 2017.

[9] M. H. Mahmadun Nuby, R. A. Rashid, M. R. Hasan. Practices and Outcomes of Communicative Language Teaching in Higher Secondary Schools in Rural Bangladesh. Qualitative Research in Education, Vol.8, No.2, 59-92, 2019.

[10] M. M. Rahman, A. Pandian, M. Kaur. Factors Affecting Teachers' Implementation of Communicative Language Teaching Curriculum in Secondary Schools in Bangladesh. The Qualitative Report, Vol.23, No.5, 1104-1126. 2018b.

[11] M. O. Hamid, R. B. Baldauf. Will CLT bail out the bogged down ELT in Bangladesh? English Today, Vol.24, No.3, 16-24, 2008.

[12] U. Hani, M. K. Siddika. The Application of English Textbook in HSC Level: A Case Study in Bangladesh. American Journal of Humanities and Social Sciences, Vol.6, No.1, 1-7, 2018.

[13] M. A. Amin. Charting the river: a case study of English language teaching in Bangladesh (Unpublished doctoral dissertation). The University of Canterbury, New Zealand, 2017.

[14] M. Al Amin, J. Greenwood. The examination system in Bangladesh and its impact: on curriculum, students, teachers and society. Language Testing in Asia, Vol.8, No.1, $1-18,2018$.

[15] N. Sultana. Test review of the English public examination at the secondary level in Bangladesh. Language Testing in Asia, Vol.8, No.1, 2018.

[16] M. M. Alam. Comparative Acceptability of GTM and CLT to the Teachers of Rural Secondary High Schools in Bangladesh. Global Journal of Human-Social Science Research, Vol.15, No.4, 1-8, 2015.

[17] R. K. Choudhury. Appropriateness and relevancy of Communicative Language Teaching (CLT) for Bangladesh: a perspective from Bangladeshi rural secondary school English teachers (Unpublished doctoral dissertation). Teachers College, Columbia University, US, 2010.

[18] M. Rasheed. Learning English language in Bangladesh: CLT and beyond. Critical Literacy: Theories and Practices, Vol.6, No.2, 31-49, 2012.

[19] M. M. Rahman, M. S. Islam, A. Karim, T. A. Chowdhury, M. M. Rahman, P. M. I. Seraj, M. K. M. Singh, English language teaching in Bangladesh today: Issues, outcomes and implications. Language Testing in Asia, Vol.9, No.1, 2019.

[20] M. Ali, A. L. Walker. Bogged down ELT in Bangladesh: Problems and policy. English Today, Vol.30, No.2, 33-38, 2014.

[21] M.S. Alam, M.H. Kabir. Assessing the Gap between Theory and Practice in Implementing CLT at Secondary Level in Bangladesh: A Case Study. Research on Humanities and Social Sciences, Vol.5, No.1, 61-68, 2015.

[22] J. C. Richards. Program factors in effective foreign and second language teaching. Journal of Southeast Asian Education, Vol. 2, No.2, 373-412, 2001.

[23] M. Fullan. Change theory as a force for school improvement. In Intelligent leadership. Doi:10.1007/978-1-4020-6022-9 3, 2007.

[24] S. Das, R. Shaheen, P. Shrestha, A. Rahman, R. Khan. Policy versus ground reality: Secondary English language assessment system in Bangladesh. Curriculum Journal, Vol.25, No.3, 326-343, 2014.

[25] M. M. Rahman, M. K. M. Singh, A. Pandian. Exploring ESL Teacher Beliefs and Classroom Practices of CLT: A Case Study. International Journal of Instruction, Vol.11, No.1, 295-310, 2018a.

[26] S. Borg. Language teacher cognition. The Cambridge guide to second language teacher education, 163-171, 2009.

[27] W. Wang. Teachers' beliefs and practices in the implementation of a new English curriculum in China: Case studies of four secondary school teachers. (Unpublished doctoral dissertation) University of Hong Kong, Hong Kong. 2008.

[28] N. C. Ellis. Essentials of a theory of language cognition. The Modern Language Journal, 103, 39-60. Doi: 10.1111/modl. 12532,2019

[29] P. Astuti. "I can teach them; they can teach me": The role of individual accountability in cooperative learning in Indonesian secondary school EFL classrooms. (Unpublished doctoral dissertation) University of Rochester, New York, USA, 2016.

[30] P. Astuti, J. C. Lammers. Making EFL instruction more CLT-oriented through individual accountability in cooperative learning. TEFLIN Journal, Vol.28, No.2, 236-259, 2017.

[31] A. Athawadi. Factors hindering the implementation of Communicative Language Teaching in Libyan university English classes, European Journal of English Language Teaching, Vol.4, No.3, 60-74, 2019.

[32] R. Jahanzaib, M. Zeeshan. University Teachers' and Students' Beliefs about Grammar Translation Method and Communicative Language Teaching in Quetta, Balochistan, Pakistan, International Journal of English Linguistics, Vol.7, No.2, 151-157, 2017.

[33] J. Luo, M. Garner. The challenges and opportunities for English teachers in teaching ESP in China, Journal of Language Teaching and Research, Vol.8, No.1, 81-86, 2017.

[34] A. Mason, C. Payant. Experienced teachers' beliefs and practices toward communicative approaches in teaching English as a foreign language in rural Ukraine, TESOL Journal, Vol.10, No.1, e377. doi: 10.1002/tesj.377, 2019.

[35] C. Mitchell. Language education pressures in Japanese high schools, JALT Shiken, Vol.21, No.1, 1-11, 2017.

[36] Smith, M. Beyond EFL: Globalizing Education in Japan. 
Journal of Aomori University of Health and Welfare, Vol.17, No.3, 45-50, 2017.

[37] G. Thompson, M. Yanagita. Backward yakudoku: an attempt to implement CLT at a Japanese high school. Innovation in Language Learning and Teaching, Vol.11, No.2, 177-187, 2017.

[38] V. Toro, G. Camacho-Minuche, E. Pinza-Tapia, F. Paredes. The Use of the Communicative Language Teaching Approach to Improve Students' Oral Skills, English Language Teaching, Vol.12, No.1, 2019.

[39] G. Susanto. Communicative Language Teaching And Its Achievements: A Study Of In-Country Program In Indonesia From 2013-2015. The 4th International Conference on Language, Society and Culture in Asian Contexts, KnE Social Sciences, 472-481, 2017.

[40] N. Muthmainnah. English corner: a setting to support CLT success enhancing students' speaking skill. IDEAS: Journal on English Language Teaching and Learning, Linguistics and Literature, Vol.5, No.1, 2017.

[41] L. Wei, H. H, Lin, F. Litton. Communicative Language Teaching (CLT) in EFL Context in Asia, Asian Culture and History, Vol.10 No.2, 1-9. 2018.

[42] D. Hymes. On Communicative Competence. In J. B. Pride and J. Holmes (eds.), Sociolinguistics, pp. 269-293. Harmondsworth: Penguin, 1972.

[43] H. G. Widdowson. Teaching Language as Communication, Oxford University Press, Oxford, 1978.

[44] M. R. A. Sarab, A. Monfared, M. M. Safarzadeh. Secondary EFL School Teachers' Perceptions of CLT Principles and Practices: An Exploratory Survey. Iranian Journal of Language Teaching Research, Vol. 4, No.3, 109-130, 2016.

[45] S. J. Savignon. Communicative competence, The TESOL Encyclopedia of English Language Teaching, 1-7, Doi: 10. 1002/9781118784235.eelt0047, 2018.

[46] J. C. Richards, T. S. Rodgers. Approaches and methods in language teaching, Cambridge University press, 2014.

[47] D. Larsen-Freeman, M. Anderson. Techniques and Principles in Language Teaching 3rd edition, Oxford university press, 2011

[48] J. W. Creswell. Qualitative inquiry and research design: Choosing among five approaches (3rd ed.), Sage, Thousand Oaks, CA, 2013.

[49] T. S. Farrell, J. Ives. Exploring teacher beliefs and classroom practices through reflective practice: A case study, Language Teaching Research, Vol.19, No.5, 594-610, 2015.

[50] I. Kuzborska. Links between teachers' beliefs and practices and research on reading, Reading in a foreign language, Vol.23, No.1, 102-128, 2011

[51] R. Khan. An evaluation of the writing component of the higher secondary English syllabus in Bangladesh (Doctoral dissertation), University of Warwick, UK, 1999.

[52] M. Hammersley. Reading ethnographic research: a critical guide, Longman, London, 1990.

[53] Y.S. Lincoln, E.G. Guba, Naturalistic inquiry, Sage,
Newbury Park, CA, 1985.

[54] M. Genzuk. A synthesis of ethnographic research, Occasional Papers Series. Los Angeles, CA: Center for Multilingual, Multicultural Research University of Southern California, 2003.

[55] B. Hancock, E. Ockleford, K. Windridge, An introduction to qualitative research, The NIHRRDS, Yorkshire, 2007.

[56] M. Hennink, I. Hutter, A. Bailey. Qualitative research methods, Sage Publications, London, 2013.

[57] L. Cohen, L. Manion, K. Morrison. Research methods in education (6th ed.), Routledge, London, 2007.

[58] J. A. Hatch. Doing qualitative research in education settings, State University of New York, New York, 2002.

[59] R.E. Boyatzis. Transforming qualitative information: thematic analysis and code development, Sage, Thousand Oaks, CA, 1998

[60] V. Braun, V. Clarke. Using thematic analysis in psychology, Qualitative research in psychology, Vol.3, No.2, 77-101, 2006.

[61] W. Luttrell. "Good enough" methods for ethnographic research, Harvard Educational Review, Vol. 70 No. 1, 499-523, 2000

[62] J. W. Creswell, C. N. Poth. Qualitative inquiry and research design: Choosing among five approaches (4th ed.), Sage, Los Angeles, CA, 2017.

[63] R. C. Bogdan, S. K. Biklen. Qualitative research for education: An introduction to theory and methods, (51 ed.) Allyn and Bacon, Inc., Boston, 2007.

[64] D. Larsen-Freeman. Techniques and Principles of Language Teaching, Oxford University Press, Oxford, 2004.

[65] M. K. Hassan. Teachers' and students' perceived difficulties in implementing communicative language teaching in Bangladesh: a critical study (Unpublished doctoral dissertation), The Open University, UK, 2013.

[66] M. R. Islam. Investigation into teachers' practice in relation to curriculum implementation in ELT in Bangladesh, (Unpublished M.Phil thesis), De Montfort University, UK, 2016.

[67] W. Littlewood. Communicative Language Teaching, Cambridge University Press, Cambridge, 1981.

[68] SK. Kwon, M. Lee, D. Shin. Educational assessment in the Republic of Korea: Lights and shadows of high-stake exam-based education system, Assessment in Education: Principles, Policy \& Practice, Vol.24, No.1, 60-77, 2017.

[69] E. Shohamy. The power of tests: A critical perspective on the uses of language tests, Routledge, London, 2014.

[70] D. Allen. Japanese cram schools and entrance exam washback, The Asian Journal of Applied Linguistics, Vol.3, No.1, 54-67, 2016.

[71] Q. Xie. Do component weighting and testing method affect time management and approaches to test preparation? A study on the washback mechanism. System, 50, 56-68, 2015 . 
[72] Y. Zhan, S. Andrews. Washback effects from a high-stakes examination on out-of-class English learning: Insights from possible self-theories, Assessment in Education: Principles, policy \& practice, Vol.21, No.1, 71-89, 2014.

[73] T. N. M. Nguyen. The cultural appropriateness of communicative language teaching: a case study of the EFL program implementation at a Vietnamese tertiary institution (Unpublished doctoral dissertation), Western Sydney University, Australia, 2016.

[74] A. Holliday. The house of TESEP and the Communicative Approach: The special needs of state English language education. ELT Journal Volume, Vol.48, No.1, 3-11, 1994.

[75] I. McGrath. Material Evaluation and Design for Language Teaching. Edinburgh University Press, Edinburgh, 2002.

[76] H. D. Brown. Teaching by Principles: An Interactive Approach to Language Pedagogy, Longman, New-York, 2001.

[77] S. J. Savignon. Beyond Communicative Language Teaching: What's ahead? Journal of Pragmatices, Vol.39, No.1, 207-220, 2007.

[78] G. Ellis. The appropriateness of the Communicative Approach in Vietnam: An interview study in intercultural communication (Unpublished Master's thesis). La Trobe University, Australia, 1994.

[79] M. S. Rahman, S. M. S. Karim. Problems of CLT in Bangladesh: Ways to improve, International Journal of Education Learning and Development, Vol.3, No.3, 75-87, 2015.

[80] D. Nunan. Language teaching methodology: A textbook for teachers, Prentice Hall, London, 1998.

[81] H. D. Brown. Principles of language learning and teaching (5th ed.), Pearson Education, Inc., New York, 2007.

[82] K. A. T. Vo, V. Pang, K. W. Lee. Teaching practicum of an English teacher education program in Vietnam, Journal of Nusantara Studies, Vol.3, No.2, 32-40, 2018.

[83] W. K. Too, E. J. Saimima. Teacher Belief and Practice in a School-Based English Language Classroom in Eastern Indonesia, Journal of Nusantara Studies, Vol.4, No.1, 211-231, 2019.

[84] A. H. A. A. Aziz, R. Ab Rashid, W. Z. W. Zainudin. The Enactment of the Malaysian Common European Framework of Reference (CEFR): National master trainer's reflection, Indonesian Journal of Applied Linguistics, Vol.8, No.2, 409-417, 2018.

[85] R. A. Rashid, S. B. Abdul Rahman, K. Yunus. Reforms in the policy of English language teaching in Malaysia, Policy Futures in Education, 15(1), 100-112. (2017). 